\title{
The Impact of Covid-19 on Pencak Silat as an Icon of Indonesian Madiun Tourism
}

\author{
Yulius Harry Widodo ${ }^{1}$, Alief Sutantohadi ${ }^{2}$, Eda Maaliah ${ }^{3}$, \\ Titik Rahayu ${ }^{4}$, B.Dhina Cantya Danastri ${ }^{5}$ \\ State Polytechnic of Madiun, J1. Serayu 84 Madiun Indonesia 1,2,3,4,5 \\ \{yulius@pnm.ac.id\}
}

\begin{abstract}
This is preliminary qualitative research, with a depth interview method aimed at describing the impact of the Covid-19 pandemic and the concept of community-based tourism as an effort to live up to the Madiun Indonesia tourism tagline "Kota Pendekar". The Covid-19 pandemic changed the order of Pencak Silat school life: shaking hands as a mandatory tradition to greetings on the chest, training with physical contact had to be temporarily stopped, washing hands, wearing masks, maintaining distance, and avoiding crowds are standard that must be obliged during training. The involvement of the community, private sector, and government in realizing Pencaksilat as a tourism icon must be carried out proportionally
\end{abstract}

Keywords: pandemic, Pencak Silat, icon, tourism.

\section{Introduction}

Madiun "Kota Pendekar" is the tagline for the vision and mission of city government 2019-2024 which stands for smart, serve, build, care, and are charismatic [1][2]. Among the pesilat (martial arts fighters), this is a form of appreciation for the silat-school that was born, raised, and developed in Madiun. As a new city branding. This branding is expected to provide new enthusiasm for the community and the Madiun City Government. Branding as a charismatic city is expected to represent all elements, such as culinary, arts, culture, tourism, and public services. A new identity to sell or increase the bargaining value of Madiun as a tourist destination in western East Java. The new identity proclaimed by the city government is intended to change the negative perceptions that are already circulating in the community. Madiun no longer wants to be known as a city that is synonymous with the dark history of the rebellion of the Indonesian Communist Party (PKI). Madiun also does not want to be known as a chaotic place during the month of Suro due to frequent clashes between the two Pencak Silat schools. The potential that can be developed as a tourist attraction in the development of one of the indigenous cultural traditions is Pencak Silat [3] [4] [5].

\section{Results and Discussions}

\subsection{Pencak Silat as Tourism Icon}

The name Pencak Silat has been used since 1948 to unite the various streams of traditional martial arts. In the beginning, the term Pencak was the name used in Java, while silat was used in Sumatra, the Malay Peninsula, and Kalimantan [6]. However, over time, the term Pencak is 
used in attractions that emphasize the elements of art and the beauty of movement. Meanwhile, the term silat is used for attractions that promote elements of the battle [7].

In the Dictionary of Indonesia Language, Pencak Silat is a game of skill in defending oneself with the ability to fend off, attack, and defend oneself. Pencak Silat is also defined as a high-level martial arts movement accompanied by feelings, so it is an effective and controlled mastery of motion and is often used in training or competition. Pencak Silat can be interpreted as the result of culture to defend oneself to maintain the existence and integrity of the environment and the surrounding environment to achieve harmony in life to increase faith in God the Creator [8]. One example of the history of Silat-schools in Indonesia, especially Madiun. Based on the history of Setia Hati Terate (SHT), a silat-school founded by Mr. Hardjo Oetomo, a resident of Pilangbango Village, Kartoharjo District, Madiun City, in 1922. $\mathrm{He}$ is a student of Ki Ngabehi Soerodiwirjo, founder of the martial arts SH (better known as SH Winongo), which is based in Winongo Village, Manguharjo District, Madiun City [9]. Historically, Pencak Silat was implicitly formatted as basic training for youth to fight against Dutch colonialism. His patriotism does not want his beloved homeland to be colonized by other nations.

SHT is growing rapidly and Several overseas commissariats were successfully inaugurated. There are commissariats of Malaysia, Netherlands, Timor Loro Sae, Hong Kong, Moscow, and Egypt. The Pencak Silat school in Madiun is very enthusiastic about making Pencak Silat together as a tourism icon. Enthusiasm to show the beauty of Pencak Silat which can be a tourism spectacle is based on the following awareness:

a) As a tourism icon, Pencak Silat can be displayed by emphasizing the beauty of movement. The concept of the performance can be carried out between internal or interPencak Silat School periodically and in turns.

b) The performance of the beauty of the movement of Pencak Silat is believed to be a place to get to know other universities which will make the atmosphere more conducive

c) As an effort to preserve the culture and strengthen the sense of brotherhood between silat-schools.

d) The idea of holding a beautiful movement performance or silat stance needs to be communicated and followed up seriously between silat-school administrators to get an agreement as to the operational guide for all the silat-schools involved.

e) As an event to show and display the diversity of movements typical of the traditional Pencak Silat of each silat-school.

f) As an event to present all silat-school regardless of the size of it. And it is hoped that even smaller silat-school can exist and be known.

g) Each silat-school will try its best to display excellence in terms of beauty, diversity, and harmony.

h) Periodically or annually carry out joint performance activities to increase brotherhood and establish harmony and as an embodiment of the Madiun icon "Kota Pendekar"

i) It is necessary to hold an election for Pencak Silat arts ambassadors, as representatives of sub-districts, schools, or silat-schools.

Over the past few years, Madiun has been synonymous with horror every time before the month of Suro. Clashes between members of the different silat-schools were frequent at that time. However, from day to day the fighting diminished. To give a new meaning by holding, the "Suro Month Festival" which can be:

a) Workshop for discovering the identity and form of Madiun "Kota Pendekar".

b) Holding competitions, exhibitions, and festivals officially for internal and inter-silatschools. 
c) Showing the abilities of the pesilat for entertaining

d) Organizing colossal beautiful silat exercises

e) Holding Pencak Silat exhibition continuously and periodically

\subsection{Community-Based Tourism}

Tourism is a system of various elements arranged like a cobweb: "like a spider's webtouch one part of it and reverberations will be felt throughout" (Mill \& Marrison, 1985: 19 in Philips and Pittman, 2009). Therefore it is not surprising that tourism involves many actors in various competitively related sectors. There are three groups of tourism actors, namely the public, the private sector, and the government. (Rusyidi 2018, 157). The community pillar refers to the general public in tourist destinations, as the legal owners of various resources that constitute tourism capital such as culture. This includes community leaders, intellectuals, nongovernmental organizations, and mass media.

The next pillar is the private sector, namely tourism business associations and entrepreneurs who are directly or indirectly related to tourism. The last pillar is the government which has authority in various administrative areas. Referring to this view, it can be concluded that tourism development should involve the three pillars. Tourism development does not only rely on the business capabilities of the private sector. Without government and community support, the development of a tourism business run by the private sector cannot run smoothly. The same thing can happen if tourism development is only managed by the government, without involving other pillars. The government will experience difficulties in increasing investment and capital in tourism development. However, the most important thing is the involvement of the pillars of the community, which has so far been neglected in tourism development. As a result, the community, especially those who live in tourist areas or destinations, often do not benefit from the tourism development around them. Even if they are involved, the role they play is minimal so that it does not have a significant impact on the welfare of the local community.

In some cases, local communities around tourist destinations are only spectators while at the same time they are affected by various negative social, economic, and environmental impacts as a result of tourism development in their area. Tourism management involves environmental, social, and community values. Everything is packaged in tourist offerings that can be enjoyed by tourists. Therefore the principles that must be considered in tourism management:

a) Involving local wisdom so that it will produce unique tourism objects in the form of local cultural traditions accompanied by natural and environmental uniqueness.

b) Every tourism potential must be protected and preserved so that it can be marketed to tourists.

c) The development of attractions as one of the tourist attractions should be developed in such a way as to reflect the values of local wisdom, society, and culture.

Tourism is a complex activity that can be viewed as a large system, consisting of various components such as economic, ecological, political, social, cultural, and so on. When tourism is seen as a system, the analysis of tourism cannot be separated from other subsystems, such as politics, socio-economy, and culture. These subsystems have interdependent and interconnected relationships or interconnectedness. This shows that changes in one subsystem will also cause changes in other subsystems until finally a new harmony is found.

Related to tourism development, Page (2007) states that there are at least five approaches in tourism development, namely : 
a) Booster approach; This approach is a simple approach that explains tourism as a positive result for a place and its inhabitants. However, this approach does not see community involvement in the planning process, and the carrying capacity of the area is not considered carefully.

b) The economic industry approach; the tourism development approach emphasizes economic goals rather than social and environmental goals and makes the experience of visitors and visitor satisfaction levels the main targets.

c) The physical spatial approach; This tourism development approach refers to geographic land use with a development strategy based on spatial (spatial) principles. For example, the division of visitor groups to avoid conflicts between visitors.

d) The community approach. A tourism development approach that emphasizes maximum community involvement in the tourism development process.

e) Sustainable approach. Tourism development by considering aspects of sustainability or future interest in resources and the impact of economic development on the environment.

Based on the five tourism approaches above, it can be said that each approach has its strengths and weaknesses. The tendency that is happening now is to emphasize the approach of community involvement without neglecting other approaches. To realize Pencak silat as a tourism icon still requires a long way to go. Comprehensive planning as a road map must be prepared and done by further study. Tourism destinations, forms of attraction, participants, the person in charge, and involvement of all silat-schools must be done. The participation of the government, society, and the private sector with their respective portions must be coordinated as well as possible.

The division of roles and involvement of the three pillars in tourism, namely the community, the private sector, and the government should be carried out proportionally. Tourism development does not only rely on the business capabilities of the private sector. Without support from the government and the community, the development of a tourism business run by the private sector cannot run smoothly. Likewise, tourism development is only managed by the government, without involving the private sector and the community. The government is predicted to experience difficulties in increasing investment and capital in tourism development. However, the most important thing is the involvement of the pillars of society as the actors who are directly involved to feel the impact.

Examining further the involvement between tourism pillars, it appears that the Madiun City Government plays a dominant role. This is evidenced by the continuous efforts to instill awareness that Pencak Silat and Madiun "Kota Pendekar" cannot be separated in everyday life. Several attempts were made by the city government to strengthen martial identity and intelligence. The installation of a pendekar (warrior) statue at a crossroads is an attempt to reminds the existence of Pencak Silat and revives the spirit of sportsmanship of the pendekar in their daily life. Meanwhile, in connection with the Covid-19, the city government introduced the tagline "Pendekar Waras" as an acronym for Health Protocol Discipline Enforcement against Corona Virus for Healthy Citizens. "Pendekar Waras" is in charge of making sure the whole community wears masks and applies health protocols. This program is an effort based on local wisdom by giving new meaning to the term warrior, as well as a reminder that Madiun is a "Kota Pendekar" in all conditions.

\subsection{Impact of the Covid-19}

It is important to note that global tourism has been exposed to a wide range of crises in the past between 2001-20015. For example, major disruptive events include the September 11 
terrorist attacks (2001), the severe acute respiratory syndrome (SARS) outbreak (2003), the global economic crisis unfolding in 2009, and the 2015 Middle East Respiratory Syndrome (MERS) outbreak. None of them led to a longer-term decline in the global development of tourism, and some of them are not even notable. This would suggest that tourism as a system has been resilient to external shocks. However, there is much evidence that the impact and recovery from the COVID-19 pandemic will be unprecedented [10]. The Covid-19, which has been going on since March 2020 until this report was compiled, has greatly influenced the continuity of training in each silat-school. Each silat-school has a different way of responding to a pandemic as follows:

a) The exercise stops temporarily

b) Exercise reduced frequency

c) Exercise is reduced in intensity

d) Eliminating physical training and turning to spiritual practice

e) Group exercises are eliminated and replaced with scheduled small group exercises

f) Keep physical exercise on schedule by strictly adhering to health protocols

The anticipation of the impact of Covid-19 was carried out in a coordinative manner through collective deliberations involving representatives of senior and junior students of silatschool. This coordination step was taken primarily to maintain the health of oneself, family, and the community. Exercises and other activities always refer to the results of concepts and methods that have been previously agreed upon in the deliberations. In connection with the health protocol as an effort to adapt to new habits to face the Covid-19 pandemic, the silatschool in Madiun is doing several things, including :

a) The silat-school allows continuing doing the exercises with the application of strict health protocols-keeping a distance, washing hands before starting and after ending activities, and masking while at the training location.

b) The silat-school decides to reduce training hours and eliminate body contact between members or sparring partners and is only limited to material exercises and spiritual exercises

c) The silat-school took part in socializing the implementation of the Covid-19 health protocol to the public by distributing masks in some locations

d) Students of silat-school who come from out of town are advised not to come and practice at silat-school or hermitage.

e) The silat-school provides hand washing facilities and hand sanitizers at the practice site. Every student and trainer is required to always wash their hands with soap before and after training. Always wear a mask or face shield at the practice site.

f) In the case of shaking hands or a direct handshake - it is obligatory - as a manifestation of brotherhood, it becomes a respectful greeting on the chest only. Health protocols become standard, such as mandatory masking, maintaining distance, and avoiding crowds, is done by arranging separate training places and scheduling

g) Reducing the duration of training time, stretching the distance during training, requiring masking while resting, always washing hands after training, bringing individual food and drink, and not sharing with friends, requiring each student to bring their own hand sanitizer.

h) Silat-school forms a covid-19 task force that collaborates with the city and is under the guidance of the Madiun City Health Office. 


\section{Conclusions}

Madiun "Kota Pendekar" (Madiun the city of warriors), which was originally the working tagline of the city government, was responded to differences among people who wanted Pencak Silat to be an attraction that lived up to the tagline of the city of warriors. The potential for Pencak Silat to be featured as an attraction that complements Madiun as a tourist destination in western East Java is constrained by the Covid-18 pandemic. Therefore, it is necessary to re-plan to realize Pencak Silat as an icon that complements the tagline of the city of warriors.

\section{Acknowledgment}

The authors would like to thank the informants. We also thank you for the State Polytechnic of Madiun for financial support to this research.

\section{References}

[1] P. W. P. Suta and I. G. A. O. Mahagangga, "Pengembangan Pariwisata Berbasis Masyarakat," Jurnal Destinasi Pariwisata, vol. 5, no. 1, p. 144, 2018.

[2] G. Dwi Cahyo Utomo, "Pencak Silat Setia Hati Terate Di Madiundari Awal Sampai Pada Masa Pendudukan Jepang," Avatara, vol. 5, no. 1, pp. 1595-1598, 2017.

[3] R. Phillips, R. \& Pittman, An Introduction to Community Development. Routledge, 2009.

[4] B. Kim, B. Dimitrios, and I. Alessandro, "Smart tourism destinations: ecosystems for tourism destination competitiveness," International Journal of Tourism Cities, vol. 2, no. 2, pp. 108-124, Jan. 2016.

[5] J. Sihite and A. Nugroho, "Exploring the Indonesian Tourism Destination via Indonesia.Travel @indtravel BT - 2nd International Conference on Tourism, Gastronomy, and Tourist Destination (ICTGTD 2018),” 2018, pp. 29-32.

[6] M. Kartomi, "Traditional and modern forms of pencak silat in Indonesia: The suku mamak in Riau," Musicology Australia, vol. 33, no. 1, pp. 47-68, 2011.

[7] I. D. Wilson, "The politics of inner power: the practice of pencak silat in West Java," 2002.

[8] D. Z. Jovicic, "From the traditional understanding of tourism destination to the smart tourism destination," Current Issues in Tourism, vol. 22, no. 3, pp. 276-282, 2019.

[9] R. Iswati, A. Wiyaka, and S. B. Utami, "Membangun Pranata sosial dalam mereduksi konflik di Perguruan Silat Setia Hati Terate (PSHT) dan Perguruan Silat Setia Hati Tunas Muda Winongo (PSHW) di Madiun," Seminar Nasional Sistem Informasi (Senasif), vol. 2, no. 1, pp. 1584-1592, 2018.

[10] S. Gössling, D. Scott, and C. M. Hall, "Pandemics, tourism and global change: a rapid assessment of COVID-19," Journal of Sustainable Tourism, vol. 0, no. 0, pp. 1-20, 2020 . 